\title{
IMPLEMENTASI APLIKASI MONITORING TINDAK LANJUT HASIL AUDIT Studi Kasus Kantor Wilayah Direktorat Bea Dan Cukai Jawa Barat
}

\author{
APPLICATION IMPLEMENTATION MONITORING FOLLOW-UP OF AUDIT RESULTS \\ A Case Study Of Regional Office Of The Directorate Of Customs And Excise In West Java
}

\author{
Budiman \\ budiman1982@gmail.com
}

\begin{abstract}
The application of Monitoring the follow-up of Audit Results is a handy application to monitor and evaluate the performance of the auditors audit against the company or the industry ranging from the publication of the letter decision issued to Task or policies of the report on Audit results. In the implementation of monitoring follow-up on audit results there are some issues which were not able to make the monitoring information at any time and it is difficult because the data in the query should open the archive in advance so it takes a long time. To ease the process of analysis and design, authors use the Classic method of Life Cycle or also called with the method waterfall. At this stage of the design process, the model used is a structured model that includes a Context Diagram and Data Flow diagrams, while for a data model using Entity Relationship diagrams. After a phase of implementation of this monitoring application can monitor the tindaklanjut audit results, simplify the user in doing data management monitoring of the follow-up of audit results and noting each letter of assignment and a follow-up letter It is published.
\end{abstract}

Keyword: Application, Monitoring, Auditing, A Letter Task

\begin{abstract}
ABSTRAK
Aplikasi Monitoring merupakan aplikasi yang berguna untuk memantau dan mengevaluasi kinerja auditor dalam pelaksanaan audit terhadap perusahaan maupun industri mulai dari diterbitkannya Surat Tugas sampai dikeluarkan keputusan atau kebijakan dari Laporan Hasil Audit. Dalam pelaksanaan monitoring tindak lanjut hasil audit terdapat beberapa masalah diantaranya tidak dapat membuat informasi monitoring setiap saat dan sulit dalam pencarian data karena harus membuka arsip terlebih dahulu sehingga membutuhkan waktu yang lama. Untuk mempermudah proses analisis dan perancangan, penulis menggunakan metode Classic Life Cycle atau biasa juga disebut dengan metode waterfall. Pada tahap perancangan, model proses yang digunakan adalah model terstruktur yang meliputi Diagram Konteks dan Data Flow Diagram, sedangkan untuk model data menggunakan Entity Relationship Diagram. Setelah dilakukan tahap implementasi aplikasi monitoring ini dapat memantau tindaklanjut hasil audit, mempermudah pengguna dalam melakukan pengelolaan data pemantauan tindak lanjut hasil audit dan mencatat setiap surat tugas dan surat tindak lanjut yang diterbitkan.
\end{abstract}

Kata Kunci: Aplikasi, Monitoring, Audit, Surat Tugas 


\section{PENDAHULUAN}

Pada era globalisasi sekarang ini teknologi semakin berkembang pesat, sistem komputerisasi menjadi salah satu bukti bahwa teknologi tidak pemah berhenti. Seiring dengan perkembangan teknologi tersebut pelaksanaan audit di Direktorat Jenderal Bea dan Cukai mulai mengimplementasikan sistem aplikasi. Aplikasi Monitoring merupakan aplikasi yang berguna untuk memantau dan mengevaluasi kinerja auditor dalam pelaksanaan audit terhadap perusahaan maupun industri mulai dari diterbitkannya Surat Tugas sampai dikeluarkan keputusan atau kebijakan dari Laporan Hasil Audit. Untuk pengolahan data pada suatu perusahaan atau instansi membutuhkan adanya program aplikasi. Program aplikasi ini dapat membantu menyajikan berbagai informasi dan laporan yang sewaktu-waktu dibutuhkan.

\subsection{Identifikasi Masalah}

Aplikasi monitoring tindak lanjut Hasil Audit merupakan aplikasi untuk memantau dan mengevaluasi dari serangkaian kegiatan daiam pelaksanaan audit yang bermula dari diterbitkannya DROA (Daftar Rencana Objek Audit) dan Rekomendasi Permintaan melalui Surat Tugas, dalam pelaksanaannya auditor harus menyusun DTS (Daftar Temuan Sementara) terhadap Perusahaan yang bersangkutan yang memuat kesimpulan sementara audit, setelah itu diterbitkan Laporan Hasil Audit yang disusun oleh Tim Audit, Laporan Hasil Audit akan dikaji ulang KPBC (Kantor Pelayanan Bea dan Cukai) sebagai tindak lanjut dari hasil pelaksanaan audit. Adapun masalahmasalah yang terjadi yaitu:

a. Tidak dapat membuat informasi setiap saat

b. Sulit dalam pencarian data karena harus membuka arsip terlebih dahulu sehingga membutuhkan waktu yang lama

\subsection{Tujuan}

Tujuan dari Pembangunan Aplikasi Monitoring Tindak Lanjut Hasil Audit ini adalah:

a. Memantau dan mengevaluasi kegiatan pelaksanaan audit baik yang telah dilaksanakan maupun yang sedang dilaksanakan. Mengetahui tindak lanjut Laporan Hasil Audit.

b. Mempermudah pengguna dalam melakukan pengelolaan data Pemantauan tindak lanjut hasil audit. 


\subsection{Batasan Masalah}

Pengamatan difokuskan pada “Aplikasi Monitoring Tindak Lanjut Hasil Audit pada Kantor Wilayah Direktorat Jendral Bea dan Cukai Jawa Barat”, yang akan dibuat melalui tahapan analisis dan perancangan pada sistem tersebut. Batasan sistem yang diamati yaitu:

a. Membantu dalam pengevaluasian dan pemantauan kineija auditor dalam pelaksanaan audit dan tindak lanjut Laporan Hasil Audit.

b. Menyediakan informasi pengambil keputusan untuk Kepala Kantor Wilayah dan Kepala Bidang Audit, seperti:

1) Mengetahui data perusahaan yang telah diaudit maupun masih dalam tahap audit.

2) Dapat membuat laporan hasil kineija tim audit.

\subsection{Metode Penelitian}

Dalam pemecahan masalah, penulis berpedoman pada rekayasa perangkat lunak. Untuk mempermudah proses analisis dan perancangan, penulis menggunakan metode Classic Life Cycle atau biasa juga disebut dengan metode waterfall (Pressman, 2002).

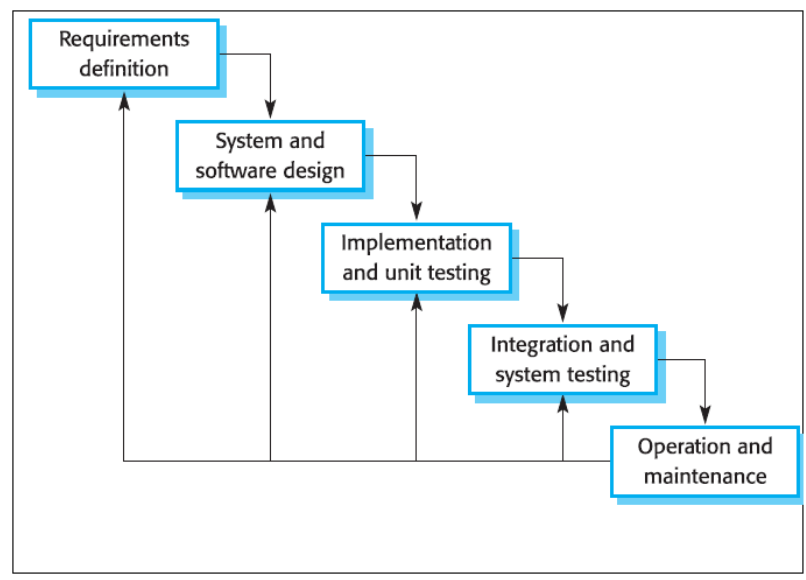

Gambar 1 Metode Waterfall

Sumber : Pressman, 2002

\section{LANDASAN TEORI}

\subsection{Aplikasi}

Menurut Nazrudin Safaat H (2012 : 9) Perangkat lunak aplikasi adalah suatu subkelas perangkat lunak komputer yang memanfaatkan kemampuan komputer langsung untuk melakukan suatu tugas yang diinginkan pengguna. Biasanya dibandingkan dengan perangkat lunak sistem yang 
mengintegrasikan berbagai kemampuan komputer, tapi tidak secara langsung menerapkan kemampuan tersebut untuk mengerjakan suatu tugas yang menguntungkan pengguna. Contoh utama perangkat lunak aplikasi adalah pengolah kata, lembar kerja, dan pemutar media. Beberapa aplikasi yang digabung bersama menjadi suatu paket kadang disebut sebagai suatu paket atau suite aplikasi (application suite). Contohnya adalah Microsoft Office dan Open Office.org, yang menggabungkan suatu aplikasi pengolah kata, lembar kerja, serta beberapa aplikasi lainnya. Aplikasi-aplikasi dalam suatu paket biasanya memiliki antarmuka pengguna yang memiliki kesamaan sehingga memudahkan pengguna untuk mempelajari dan menggunakan setiap aplikasi. Sering kali, aplikasi ini memiliki kemampuan untuk saling berinteraksi satu sama lain sehingga menguntungkan pengguna.

\subsection{Monitoring}

Menurut (Cassely dan Kumar 1987) Monitoring merupakan program yang terintegrasi, bagian penting dipraktek manajemen yang baik dan arena itu merupakan bagian integral di manajemen sehari-hari.

Sedangkan menurut (Calyton dan Petry 1983) monitoring sebagai suatu proses mengukur, mencatat, mengumpulkan, memproses dan mengkomunikasikan informasi untuk membantu pengambilan keputusan manajemen program atau proyek.

\subsection{Tindak Lanjut}

Menurut Hiro Tugiman (2006 : 72) tindak lanjut adalah suatu proses untuk menentukan kecukupan, keefektifan, dan ketepatan waktu dari berbagai tindakan yang dilakukan oleh manajemen terhadap berbagai temuan pemeriksaan audit yang dilaporkan.

\subsection{Audit}

Berikut ini adalah pengertian audit menurut para ahli :

a. Menurut (Sukrisno Agoes , 2004), Audit adalah pemeriksaan yang dilakukan untuk secara kritis dan sistematis oleh pihak yang independen, laporan keuangan yang disusun oleh manajemen dan catatan akuntansi dan bukti pendukung, dalam rangka memberikan pendapat atas kewajaran laporan keuangan.

b. Menurut (Arens dan Loebbecke, 2003), Auditing sebagai proses pengumpulan dan evaluasi bukti informasi yang dapat diukur pada suatu entitas ekonomi yang membuat kompeten dan independen untuk dapat menentukan dan melaporkan informasi sesuai dengan kriteria yang telah ditetapkan. Audit harus dilakukan oleh independen dan kompeten. 
c. Menurut (Mulyadi , 2002), Auditing adalah proses yang sistematis untuk memperoleh dan mengevaluasi bukti secara objektif atas tuduhan kegiatan ekonomi dan kegiatan dengan tujuan untuk menetapkan tingkat kesesuaian antara laporan dengan kriteria yang telah ditetapkan, serta penyampaian hasil kepada pengguna yang bersangkutan.

\subsection{Flowmap}

Definisi flowmap menurut Bin Ladjamudin (2005) adalah sebagai berikut :

"Flowmap adalah bagan-bagan yang mempunyai arus yang menggambarkan langkah-langkah penyelesaian suatu masalah. Flowmap merupakan cara penyajian dari suatu algoritma”.

Bagian alir terdiri dari lima macam, yaitu :

a. Bagan alir sistem (systems flowmap)

b. Bagan alir dokumen (document flowmap)

Bagan alir dokumen atau disebut juga bagan alir formulir atau paperwork flowmap merupakan bagan alir yang menunjukan arus dari laporan dan formulir dan termasuk tembusantembusannya. Pada penyusunan penelitian ini, penulis menggunakan bagan alir seperti berikut :
a. Bagan alir skematik (schematic flowmap)
b. Bagan alir program (program flowmap)
c. Bagan alir proses (prosess flowmap)

\subsection{Diagram Konteks}

Menurut Jogiyanto (2005) Diagram konteks adalah diagram yang terdiri dari suatu proses dan menggambarkan ruang lingkup suatu sistem. Diagram konteks merupakan level tertinggi dari DFD yang menggambarkan seluruh input ke sistem atau output dari sistem. Ia akan memberi gambaran tentang keseluruhan sistem. Sistem dibatasi oleh boundary yang dapat digambarkan dengan garis putus. Dalam diagram konteks hanya ada satu proses. Tidak boleh ada data store dalam diagram konteks.

\subsection{Data Flow Diagram}

Menurut Jogiyanto (1990:263) DFD sering digunakan untuk menggambarkan suatu sistem yang telah ada atau sistem baru yang akan dikembangkan secara logika tanpa mempertimbangkan lingkungan fisik dimana data tersebut mengalir. DFD merupakan alat yang digunakan pada 
metodologi pengembangan sistem yang terstruktur dan dapat mengembangkan arus data di dalam sistem dengan terstruktur dan jelas.

Simbol-Simbol yang digunakan pada DFD :

a. External Entity atau Boundary

External entity atau kesatuan luar merupakan kesatuan di lingkungan luar sistem yang dapat berupa orang, organisasi atau sistem lainnya yang berada di lingkungan luarnya yang akan memberikan input atau menerima output dari sistem. External entity disimbolkan dengan notasi kotak.

b. Arus Data

Arus Data (data flow) di DFD diberi simbol panah. Arus data ini mengalir di antara proses, simpanan data (data store) dan kesatuan luar (external entity). Arus data ini menunjukkan arus data yang dapat berupa masukan untuk sistem atau hasil dari proses sistem.

c. Proses

Suatu proses adalah kegiatan yang dilakukan oleh orang, mesin, atau komputer dari hasil suatu arus data yang masuk ke dalam proses untuk menghasilkan arus data yang akan keluar dari proses. Simbol proses berupa lingkaran atau persegi panjang bersudut tumpul.

d. Simpanan Data

Simpanan data merupakan simpanan dari data yang ndapat berupa hal-hal sebagai berikut, sebagai gambaran:

1) Suatu file atau database di sistem komputer.

2) Suatu arsip atau catatan manual.

3) Suatu kotak tempat data di meja seseorang.

4) Suatu tabel acuan manual.

Simpanan data di DFD disimbolkan dengan sepasang garis horizontal paralel yang tertutup di salah satu ujungnya

\subsection{Kamus Data}

Kamus data menurut Andri Kristanto (2008:72) yaitu, "Kumpulan elemen-elemen atau simbol-simbol yang digunakan untuk membantu dalam penggambaran atau pengidentifikasian setiap field atau file di dalam sistem." Bisa dikatakan bahwa kamus data merupakan tempat penyimpanan semua struktur dan elemen datan yang ada pada sistem. Juga sebagai katalog untuk mengetahui detail data seperti sumber dan tujuan data, deskripsi, bentuk, dan struktur dari data. 
Kamus data dapat digunakan sebagai alat komunikasi antara analisis sistem dengan pemakai sistem tentang data yang mengalir pada sistem.

\subsection{Entity Relational Diagram}

Menurut Jogiyanto (1990) Entity Relational Diagram atau ERD merupakan penggambaran hubungan antara beberapa entity yang digunakan untuk merancang database yang akan diperlukan.

Sebuah ERD memiliki beberapa jenis model yaitu :

a. Conceptual Data Model ( CDM )

Merupakan model yang universal dan dapat menggambarkan semua struktur logic database ( DBMS ), dan tidak bergantung dari software atau pertimbangan struktur data storage. Sebuah CDM dapat diubah langsung menjadi PDM.

b. Physical Data Model ( PDM )

Merupakan model ERD yang telah mengacu pada pemilihan software DBMS yang spesifik. Hal ini sering kali berbeda dikarenakan oleh struktur database yang bervariasi, mulai dari model schema, tipe data penyimpanan dan sebagainya.

ERD memiliki 4 jenis objek, yaitu :

a. Entity

Sesuatu yang ada dan terdefinisikan bisa berupa nyata maupun abstrak yang dapat dibedakan satu dengan yang lainnya dan adanya hubungan saling ketergantungan.

b. Attribute

Setiap entity memiliki beberapa attribute, yang merupakan cirri atau karakteristik dari entity tersebut. Attribute sering disebut juga data elemen atau data field.

c. Key

Beberap elemen data memiliki sifat, dengan mengetahui nilai yang telah diberikan oleh sebagian elemen data dari entity tertentu, dapat diidentifikasi nili - nilai yang terkandung dalam elemen-elemen data lain ada entity yang sama. Elemen penentu tersebut adalah sebagai elemen dat kunci ( key ).

d. Relationship

Relationship menggambarkan hubungan yang terjadi antar entity yang mewujudkan pemetaan antar entity. Bentuk relationship yaitu :

1) One to One Relationship Hubungan satu entity dengan entity yang lain. 
2) One to Many Relationship

Hubungan satu entity dengan entity yang lainnya adalah satu berbanding banyak.

3) Many to Many Relationship

Hubungan antar entity satu dengan entity yang lainnya adalah satu berbanding banyak.

\subsection{Konsep Basis Data}

Menurut Marlinda (2004:1), database adalah suatu susunan/kumpulan data operasional lengkap dari suatu organisasi/perusahaan yang diorganisir/dikelola dan disimpan secara terintegrasi dengan menggunakan metode tertentu menggunakan komputer sehingga mampu menyediakan informasi optimal yang diperlukan pemakainya.

\subsection{Sistem Basis Data}

Menurut Marlinda (2004:1), sistem basis data adalah suatu sistem menyusun dan mengelola record-record menggunakan komputer untuk menyimpan atau merekam serta memelihara dan operasional lengkap sebuah organisasi/perusahaan sehingga mampu menyediakan informasi optimal yang diperlukan pemakai untuk proses mengambil keputusan.

\subsection{MySQL}

Menurut Arief (2011d:152) "MySQL adalah salah satu jenis database server yang sangat terkenal dan banyak digunakan untuk membangun aplikasi web yang menggunakan database sebagai sumber dan pengolahan datanya”.

MySQL dikembangkan oleh perusahaan swedia bernama MySQL AB yang pada saat ini bernama Tcx DataKonsult AB sekitar tahun 1994-1995, namun cikal bakal kodenya sudah ada sejak tahun 1979. Awalnya Tcx merupakan perusahaan pengembang software dan konsultan database, dan saat ini MySQL sudah diambil alih oleh Oracle Corp. Kepopuleran MySQL antara lain karena MySQL menggunakan SQL sebagai bahasa dasar untuk mengakses databasenya sehingga mudah untuk digunakan, kinerja query cepat, dan mencukupi untuk kebutuhan database perusahaanperusahaan yang berskala kecil sampai menengah, MySQL juga bersifat open source (tidak berbayar) .

MySQL merupakan database yang pertama kali didukung oleh bahasa pemrograman script untuk internet (PHP dan Perl). MySQL dan PHP dianggap sebagai pasangan software pembangun 
aplikasi web yang ideal. MySQL lebih sering digunakan untuk membangun aplikasi berbasis web, umumnya pengembangan aplikasinya menggunakan bahasa pemrograman script PHP.

MySQL didistribusikan dengan licensi open source GPL (General Public License) mulai versi 3.23 pada bulan juni 2000. Software MySQL bisa diunduh melalui website resminya di http://www.MySQL.org atau di http://www.mysql.com.

\subsection{Bahasa Pemrograman Delphi}

Bahasa pemrograman Delphi adalah pemrograman berorientasi objek yang merupakan pengembangan dari bahasa pemrograman Pascal. Pascal adalah pemrograman berbasis DOS yang dibuat pada tahun 1971 oleh Niklaus Wirth dari Swiss. Kata Pascal diambil dari nama matematikiawan dan ahli filsafat dari Perancis, yaitu Blaise Pascal yang lahir tahun 1623 dan meninggal tahun 1662. Pascal dirilis tahun 1983 oleh Borland International, salah satu perusahaan software terkemuka di California.

Pada tahun 1993, Borland International mengembangkan bahasa pemrograman pascal yang bersifat visual yang disebut Delphi dan resmi dipasarkan pada tahun 1995. Pemrograman ini dibuat secara modern yang berjalan di Sistem Operasi Windows mulai dari versinya yang pertama yaitu Delphi 1 dan di tahun-tahun berikutnya Delphi terus dikembangkan mengikuti kebutuhan zaman (Kani, Firmansyah, \& Sufandi, 2010).

Integrated Development Environment atau IDE Delphi merupakan tampilan terintegrasi dimana terlihat menu dan tools yang terpisah akan tetapi sangat berhubungan yang merupakan satu kesatuan yang utuh dalam satu koordinasi. Berfungsi sebagai pusat control mulai dari menu utama, komponen pallet, form, code editor, object inspector dan object treeview yang digunakan untuk mendesain, menulis kode program serta mengatur tampilan aplikasi dalam berbagai model (Madcoms, 2003).

Untuk mengakses database, Delphi menyediakan berbagai mekanisme data akses, antara lain (Yanuar \& Hakim, 2004):

a. Borland Database Engine atau BDE

BDE adalah teknologi yang dikeluarkan oleh Borland.BDE berasal dari paradox, kemudian diperluas oleh Borland untuk mendukung banyak SQL Serverdan Database Lokal sebelum Delphi ada. BDE mengakses langsung tabel-tabel dBase, Paradox, ASCII, Foxfro dan access. Driver-driver yang ada di Delphi Enterprise memungkinkan pengaksesan ke beberapa SQL 
Server termasuk Oracle, Sybase, Microsoft, Informix, Interbase dan IBM DB2 Server. sedagkan untuk pengaksesan ke database lain disediakan ODBC Drivers.

b. ActiveX Data Object atau ADO

ADO adalah antarmuka tingkat tinggi (hight level) yang digunakan untuk mengakses database dari Microsoft. ADO diimplementasikan pada teknologi OLE DB Data Access Microsoft yang menyediakan akses ke database relasional maupun database non relasional, termasuk email, file sistem dan file lainnya.

c. Database Express Library atau dbExpress dbExpress adalah library pengaksesan yang bersifat cross-flatform untuk windows dan linux. tidak seperti BDE dan ADO, dbExpress menggunakan pendekatan kelas ringan.

d. Interbase Express atau IBExpress

Delphi menyediakan komponen-komponen untuk mengakses produknya yang gratis dan open source, yaitu interbase server. Jika menggunakan interbase sebagai back end, dapat memperoleh kinerja baik dan kemungkinan memelihara server dari aplikasi client jika menggunkan komponen khusus interbase.

\section{PERANCANGAN DAN IMPLEMENTASI}

\subsection{Diagram Konteks}

Pada gambar di bawah menunjukkan gambaran sistem secara keseluruhan dari Aplikasi Monitoring Tindak Lanjut Hasil Audit. 


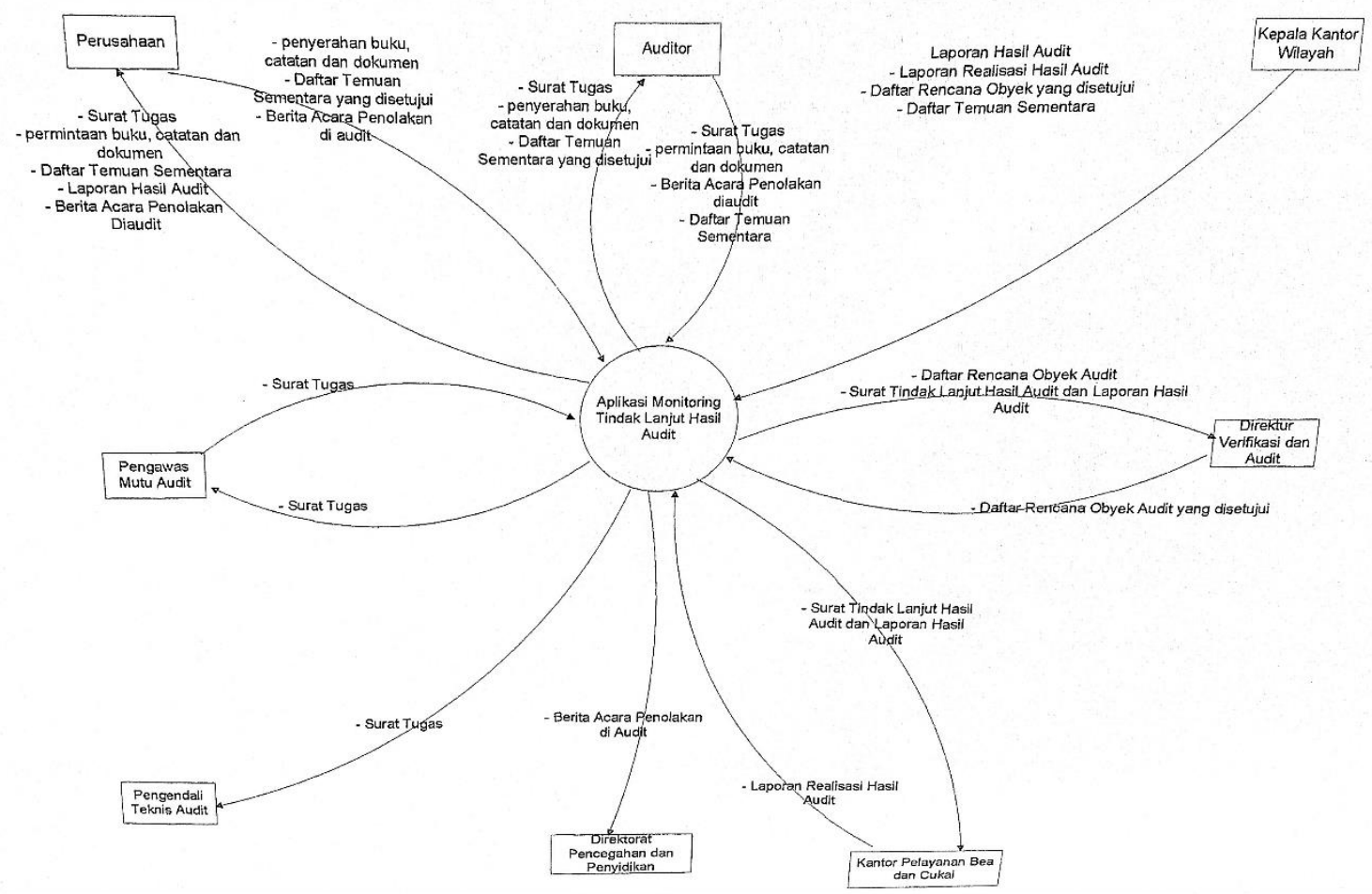

Gambar 2 Diagram Konteks

\subsection{DFD Level 0}

Pada gambar di bawah ini merupakan gambar DFD Level 0 yang menjelaskan proses-proses yang terdapat dalam Aplikasi Monitoring Tindak Lanjut Hasil Audit.

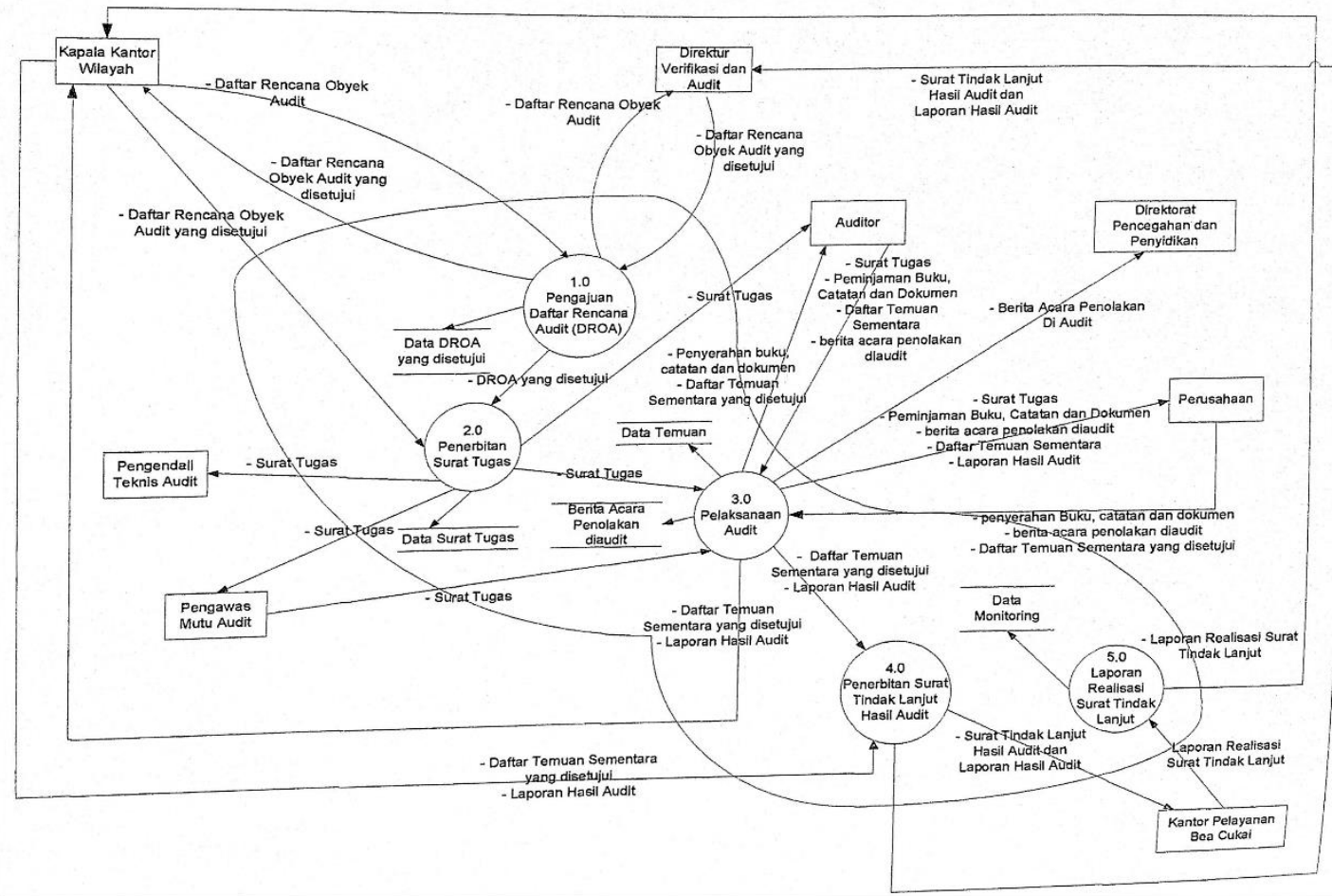

Gambar 3 DFD Level 0 


\subsection{DFD Level 1 Proses 1.0 Pengajuan Daftar Rencana Objek Audit (DROA)}

Pada gambar dibawah ini menjelaskan proses DFD Level 1 pada proses Pengajuan Daftar Rencana Objek Audit.

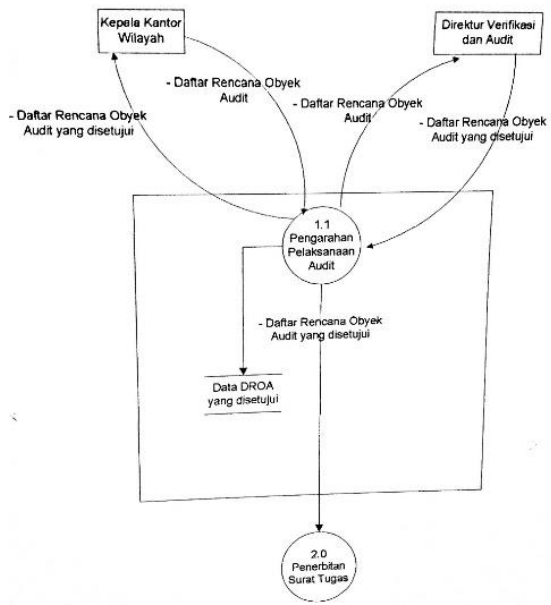

Gambar 3 DFD Level 1 Proses 1.0 Pengajuan DROA

\subsection{DFD Level 1 Proses 3.0 Pelaksanaan Audit}

Pada gambar dibawah ini menjelaskan gambaran proses dari DFD Level 1 Proses 3.0 Pelaksanaan Audit

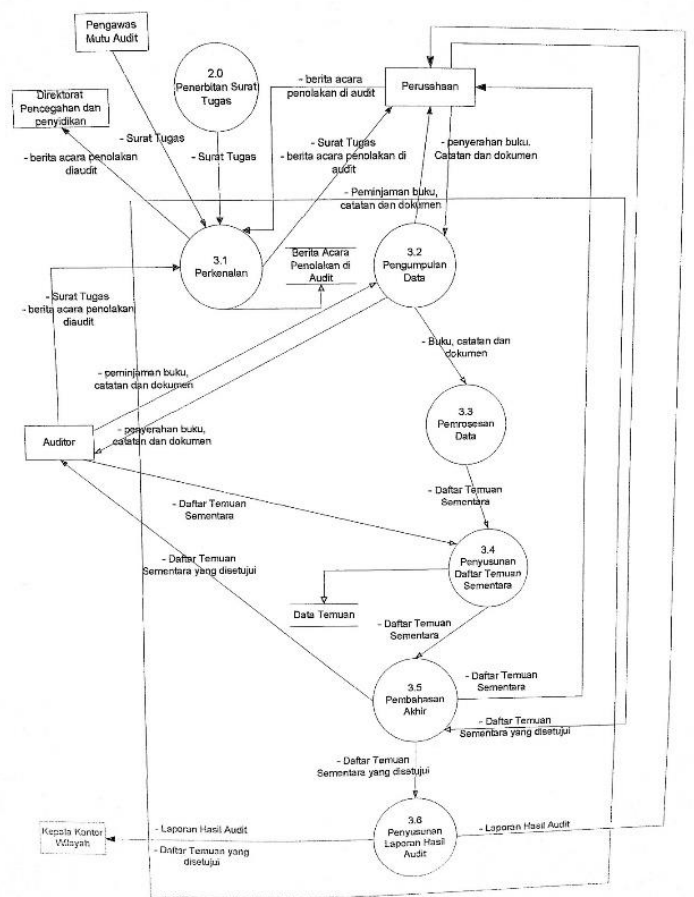

Gambar 3 DFD Level 1 Proses 3.0 Pelaksanaan Audit 


\subsection{DFD Level 1 Proses 4.0 Penerbitan Surat Tindak Lanjut Hasil Audit}

Pada gambar dibawah ini menjelaskan gambaran proses dari DFD Level 1 Proses 4.0 Penerbitan Surat Tindak Lanjut Hasil Audit.

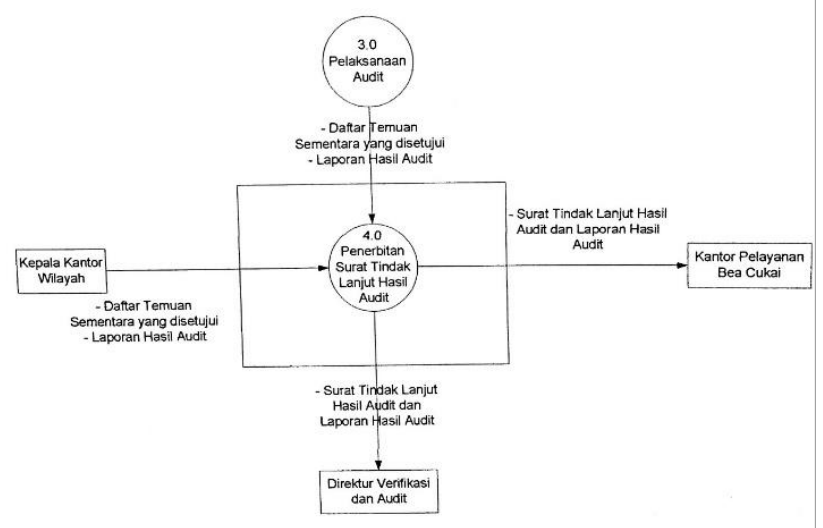

Gambar 3 DFD Level 1 Proses 4.0 Penerbitan Surat Tindak Lanjut Hasil Audit

\subsection{Entity Relationship Diagram}

Perancangan Basis data pada perancangan sistem ini meliputi perancangan ERD atau Entity Relationship Diagram. Perancangan ERD dapat dilihat pada gambar berikut ini :

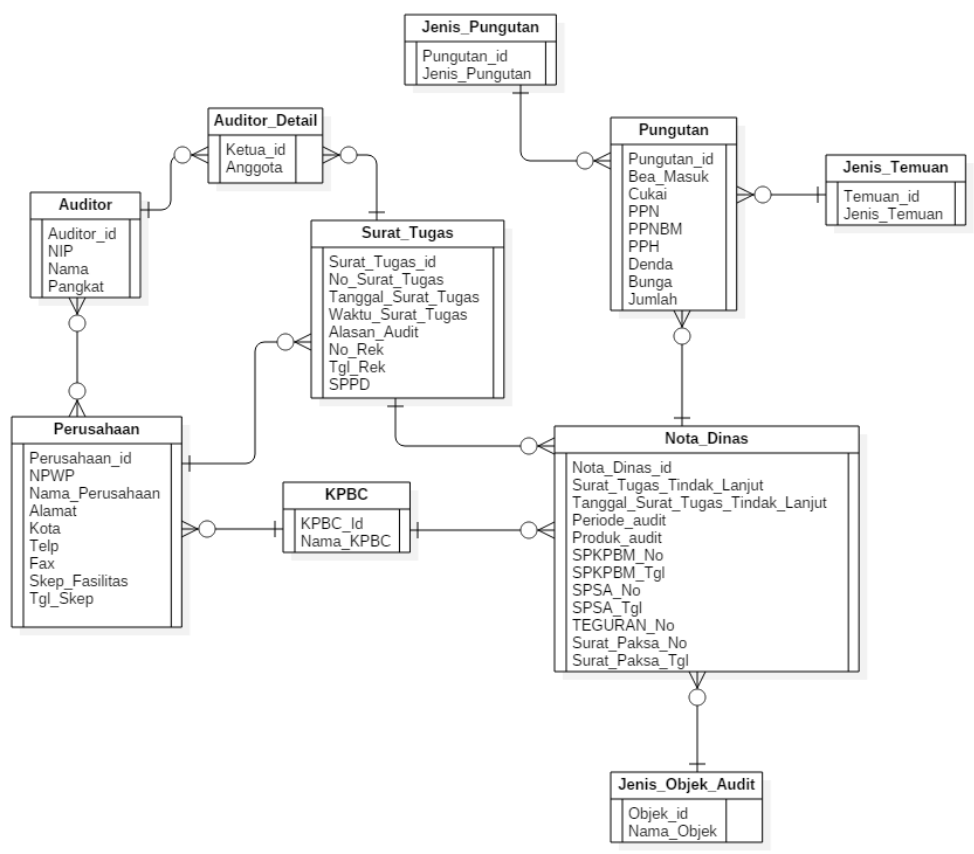

Gambar 4 Entity Relationship Diagram 


\subsection{Struktur Proses}

Pada gambar dibawah ini menjelaskan struktur proses dari Aplikasi Monitoring Tindak Lanjut Hasil Audit.

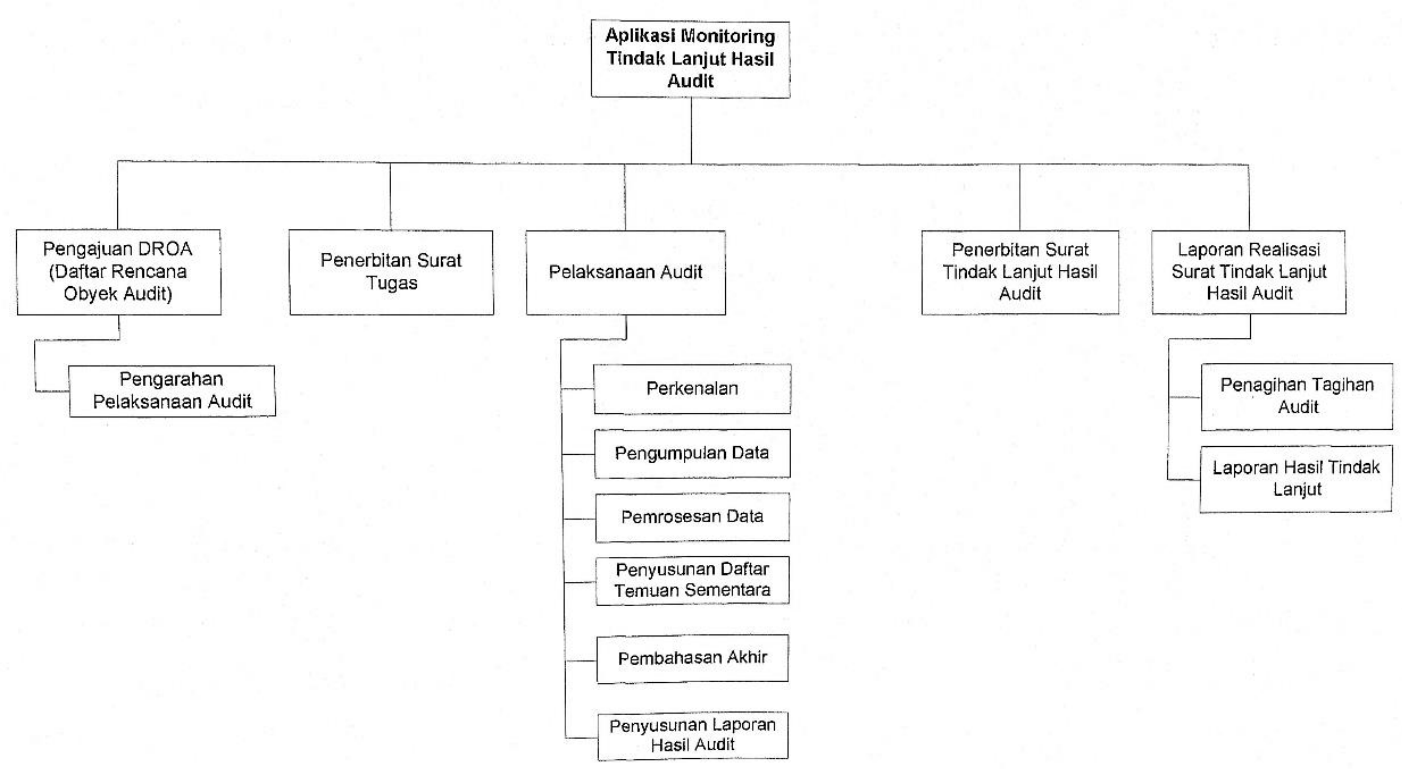

Gambar 5 Struktur Proses

\subsection{Struktur Menu}

Berdasarkan hasil analisis dan perancangan, maka untuk struktur menu yang dirancang pada aplikasi ini dapat digambarkan sebagai berikut :

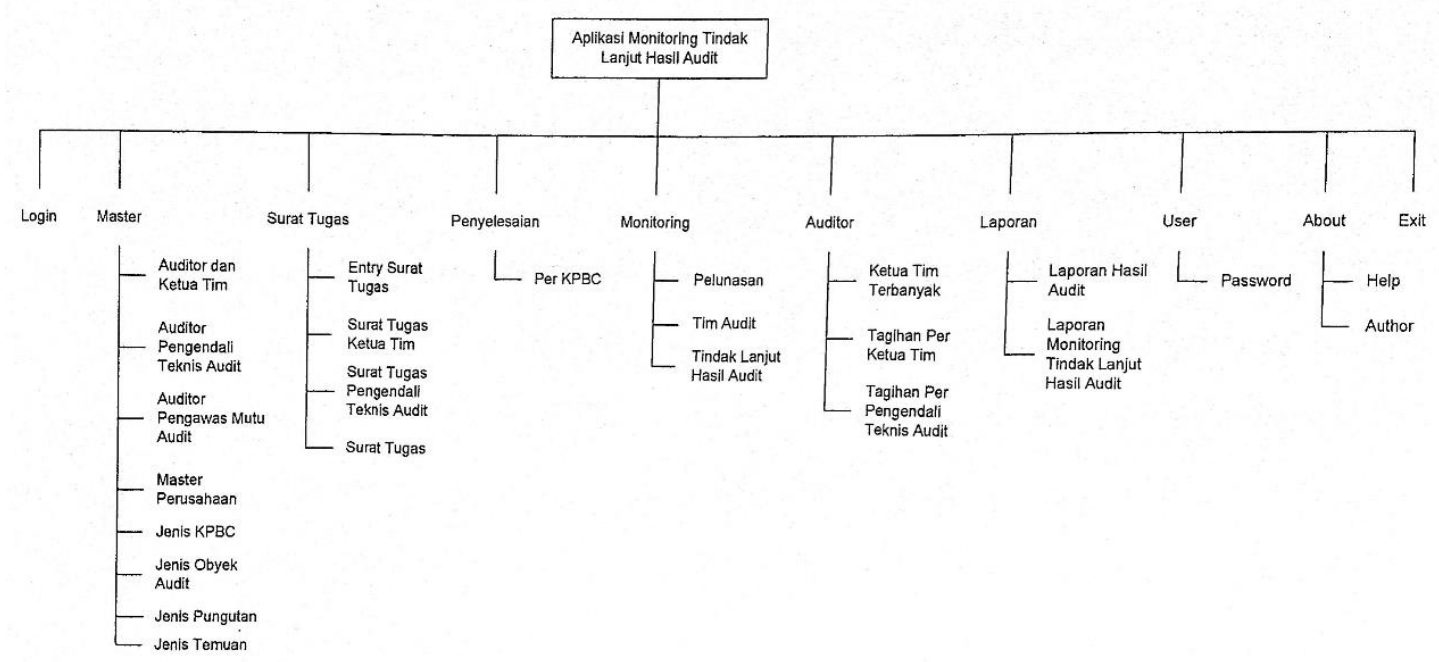

Gambar 6 Struktur Menu 


\subsection{Implementasi}

Tahap implementasi ini merupakan tahapan penerapan aplikasi dari hasil perancangan sistem untuk mencapai sesuai dengan kebutuhan. Implementasi basis data menggunakan MySQL Server dengan koneksi menggunakan MyODBC.

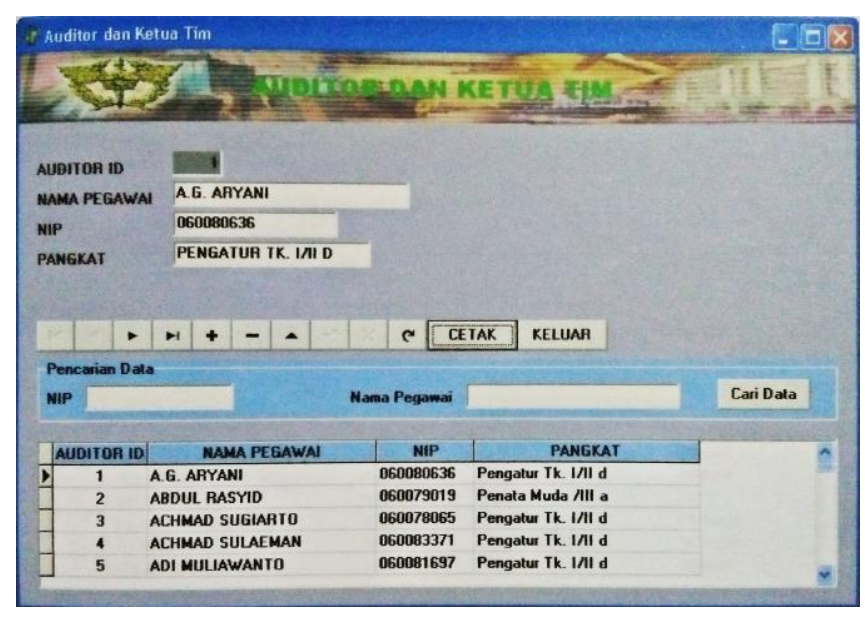

\section{Gambar 7 Auditor dan Ketua Tim}

Pada gambar 7 merupakan form master untuk mengelola data Auditor dan Ketua Tim, pada form ini pengguna dapat melakukan manipulasi data.

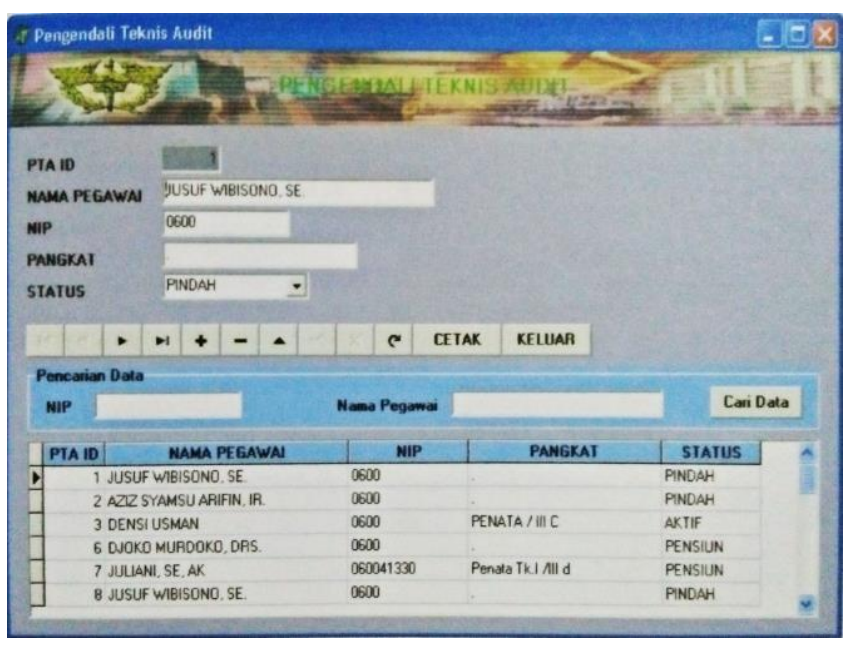

\section{Gambar 8 Pengendali Teknis Audit}

Pada gambar 8 merupakan form untuk mengelola data Pengendali Teknis Audit, pada form ini pengguna dapat melakukan manipulasi data Pengenfali Teknis Audit. 


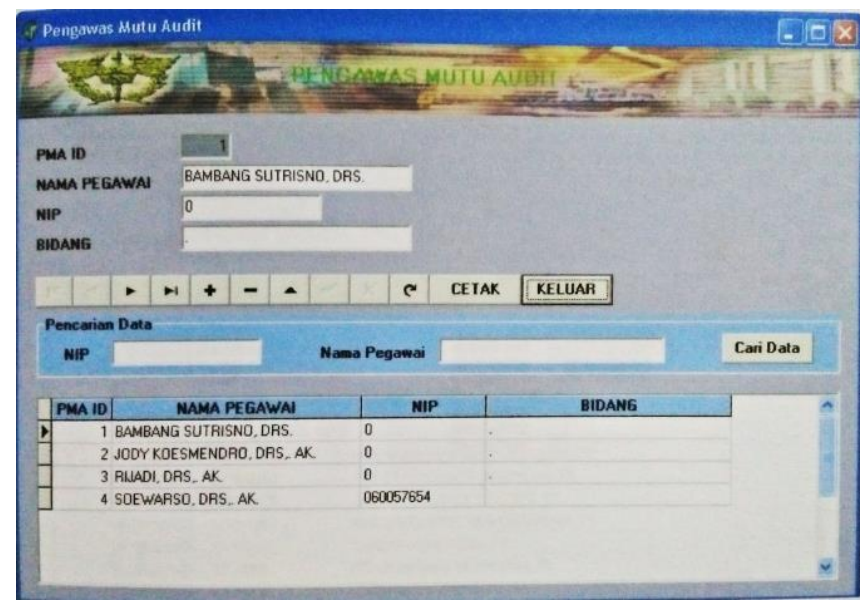

Gambar 9 Pengawas Mutu Internal

Pada gambar 9 merupakan form Pengawas Mutu Internal, pada form ini pengguna dapat melakukan manipulasi data Pegawas Mutu Internal.

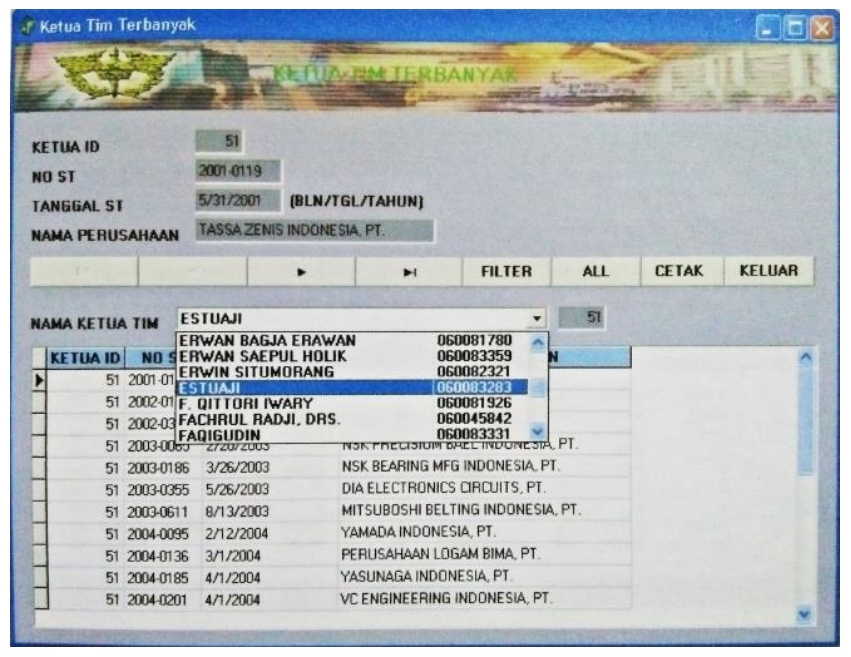

\section{Gambar 10 Ketua Tim Terbanyak}

Pada gambar 10 merupakan form Ketua Tim Terbanyak, pengguna dapat memperoleh informasi mengenai Auditor dengan status Ketua Tim terhadap Objek Audit yang dilakukan. 


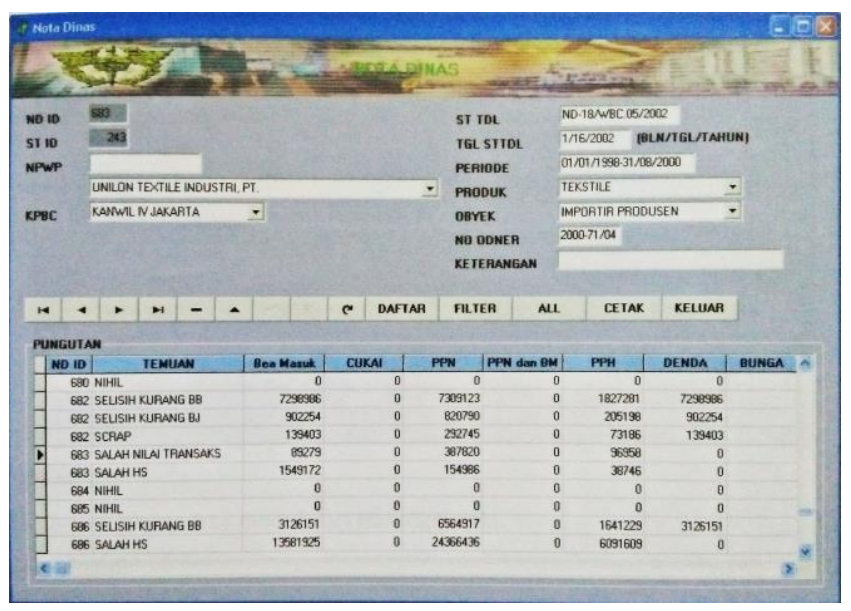

\section{Gambar 11 Nota Dinas}

Pada gambar 11 merupakan form Nota Dinas, pengguna dapat melakukan manipulasi untuk data Nota Dinas yang telah diterbitkan.

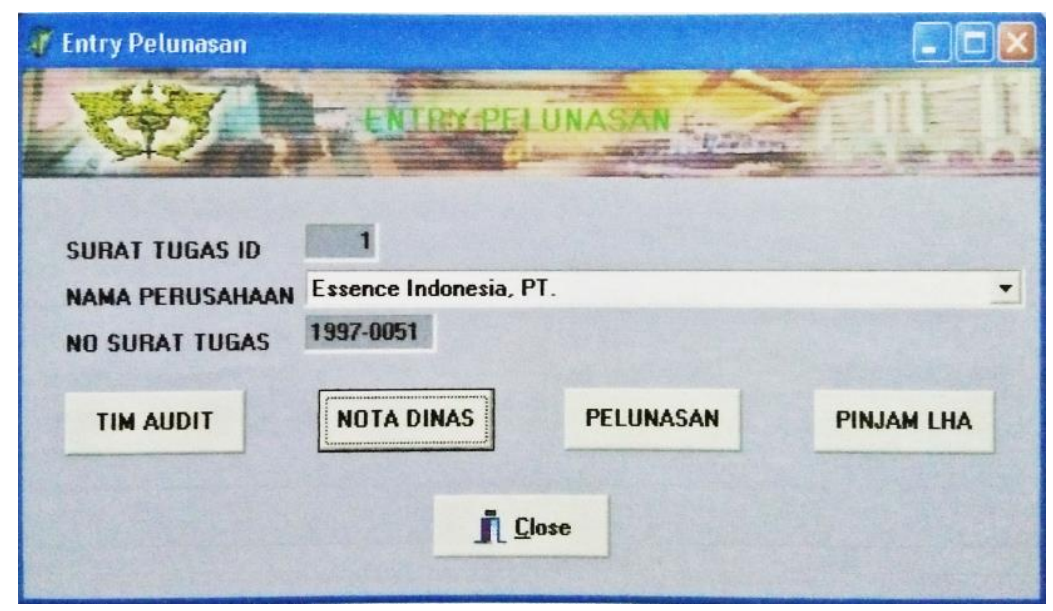

Gambar 12 Entry Pelunasan

Pada gambar 12 merupakan form Entry Pelunasan, pada form ini pengguna dapat melakukan entry pelunasan untuk status audit yang dilaksanakan berdasarkan Tim Audit, Nota Dinas, Pelunasan dan Pinjam LHA. 


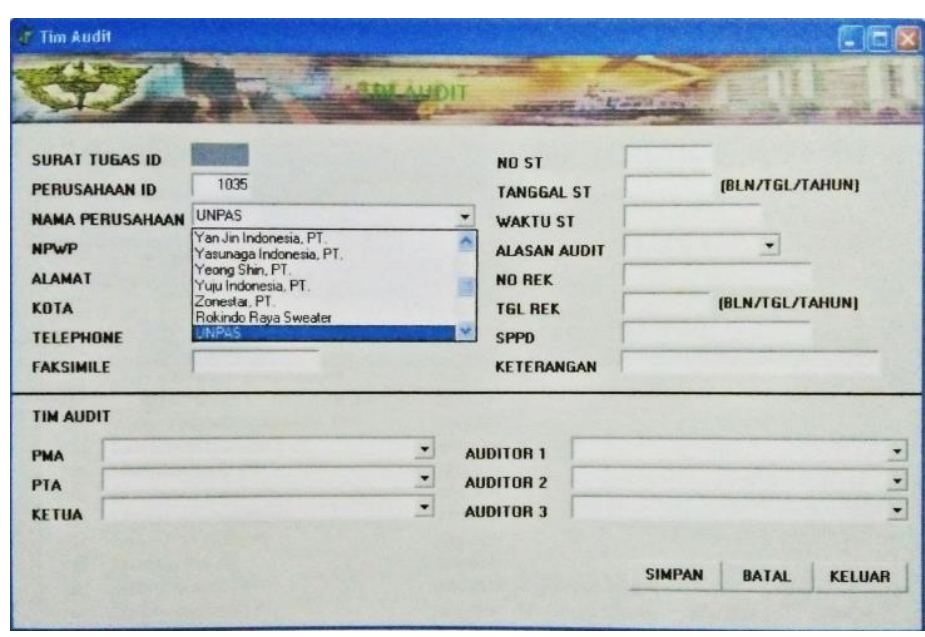

Gambar 13 Tim Audit

Pada gambar 13 merupakan form untuk Tim Audit, pengguna dapat membuat atau menyimpan data Tim Audit

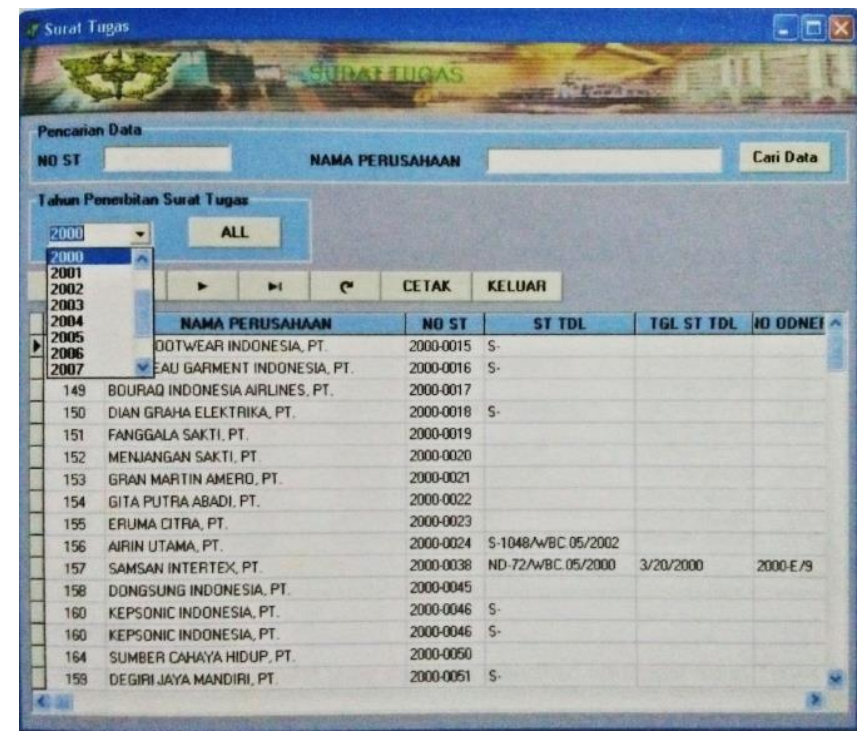

\section{Gambar 14 Surat Tugas}

Pada gambar 14 merupakan form Surat Tugas, pengguna dapat memperoleh informasi data Surat Tugas yang dikeluarkan dalam pelaksanaan audit. 


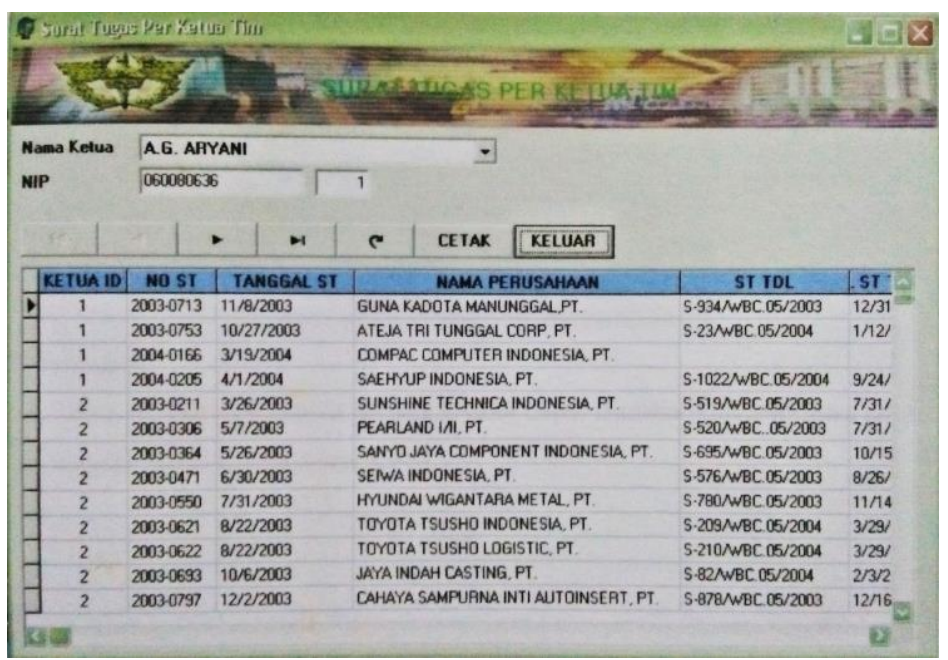

\section{Gambar 15 Surat Tugas Per Ketua Tim}

Pada gambar 15 merupakan form Surat Tugas Per Ketua Tim, form tersebut dapat memberikan informasi data Surat Tugas berdasarkan Ketua Tim.

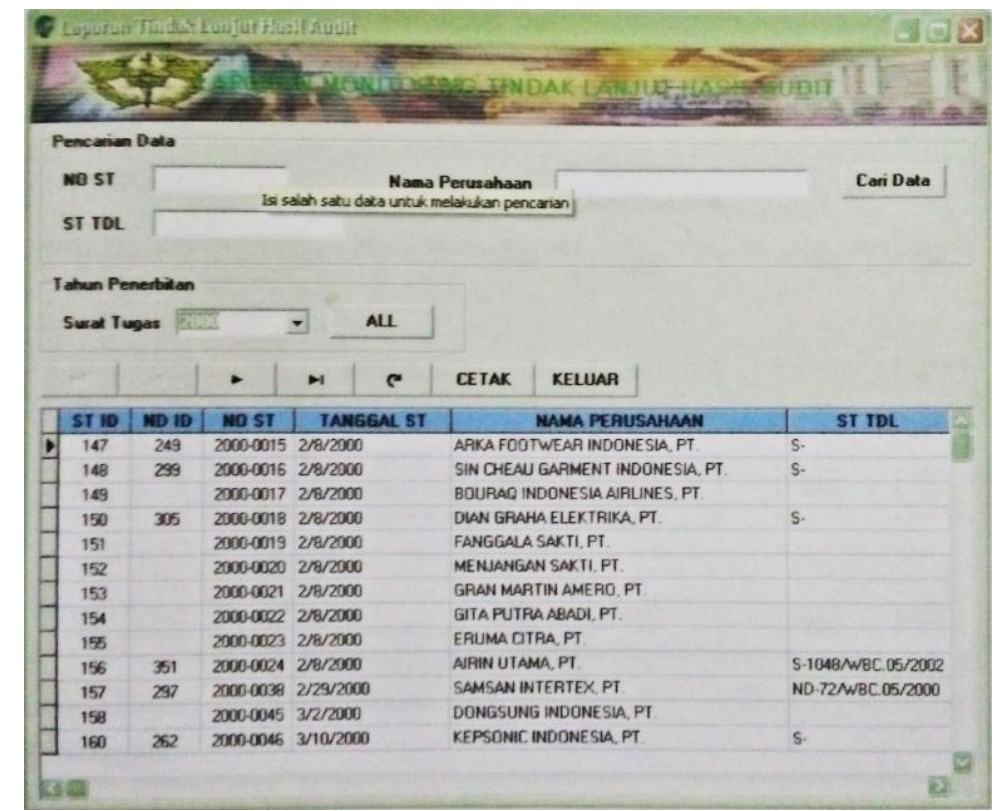

\section{Gambar 16 Laporan Monitoring Tindak Lanjut Hasil Audit}

Pada gambar 16 merupakan form Laporan Monitoring Tindak Lanjut Hasil Audit, pada form tersebut pengguna dapat memperoleh informasi data tindak lanjut setelah proses pelaksanaan audit dilakukan. 


\section{KESIMPULAN DAN SARAN}

\subsection{Kesimpulan}

Berdasarkan hasil implementasi sistem, maka dapat ditarik kesimpulan sebagai berikut:

1) Sistem aplikasi ini bertujuan untuk mendata surat tugas audit.

2) Dapat memantau tindaklanjut hasil audit.

3) Dapat mempermudah pengguna dalam melakukan pengelolaan data pemantauan tindak lanjut hasil audit.

4) Setiap surat tugas dan surat tindak lanjut yang diterbitkan akan dicatat.

\subsection{Saran}

Supaya sistem dapat berjalan dengan baik, maka saran yang dapat dilakukan adalah sebagai berikut

1) Untuk Surat Tugas, Tindak Lanjut Hasil Audit, Laporan Hasil Audit, Laporan Monitoring Tindak Lanjut Hasil Audit dibuat dan disimpan per tahun.

2) Untuk NPWP wajib diisi, karena NPWP merupakan identitas wajib pajak dari perusahaan yang diaudit.

3) Peranan manusia sebagai pengguna banyak yang tidak dapat digantikan oleh komputer misal dalam hal penentuan keputusan-keputusan tertentu dimana peranan manusia mutlak diperlukan karena komputer tidak akan mempertanggungjawabkan bila keputusan-keputusan yang ada dibuat oleh komputer.

4) Untuk menggunakan sistem ini, harus dipikirkan secara matang apakah sumber daya manusia yang ada sudah mendukung atau masih memerlukan pelatihan serta bagaimana kesiapan dari fasilitas-fasilitas dalam mendukung sistem tersebut, sehingga dengan pertimbanganpertimbangan tersebut diharapkan sistem akan lebih bermanfaat.

\section{DAFTAR PUSTAKA}

Andri Kristanto, 2008. Perancangan Sistem Informasi. Gava Media. Yogyakarta. Jakarta.

Arens dan Loebbecke. 2003. Auditing Pendekatan Terpadu. Edisi Indonesia. Salemba Empat.

Arief, M.Rudianto. 2011. Pemrograman Web Dinamis Menggunakan Php dan Mysql. ANDI. Yogyakarta.

Bin Ladjamudin, Al Bahra. 2005. “Analisis dan Desain Sistem Informasi”. Graha Ilmu. Tangerang.

Casely, D. And Kumar, 1987. Project Monitoring and Evaluation in Agriculture.

Clayton, Eric, Petry Francoise.1983. Monitoring for Agricultural and Rural Development. Projects. Vol 2 : Food \& Agriculture Org. The Macmillan. London.

Hiro Tugiman. 2006. Standar Profesional Audit Internal. Kanisius. Yogyakarta.

Hartono, Jogiyanto. 1990. Analisa dan Desain Sistem Informasi. Yogyakarta : Penerbit Andi. 
Jogiyanto, H.M., 2005, Analisa dan Desain Sistem Informasi: Pendekatan. Terstruktur Teori dan Praktik Aplikasi Bisnis, ANDI, Yogyakarta.

Kani., Firmansyah., \& Sufandi, Unggul Utan. 2010. Pemrograman Database Menggunakan Delphi Win32 dan MySQL 5.0 dengan Optimalisasi Komponen ZeosDBO. Graha Ilmu. Yogyakarta.

Madcoms. (2003). Pemrograman Borland Delphi 7. Andi. Yogyakarta.

Marlinda, Linda. 2004. Sistem Basis Data. Andi Offset. Yogyakarta.

Mulyadi, 2002. Auditing. Buku Dua. Edisi Ke Enam. Salemba Empat. Jakarta.

Nazruddin Safaat H. 2012 (Edisi Revisi). Pemograman Aplikasi Mobile. Smartphone dan Tablet PC Berbasis Android. Informatika. Bandung.

Sukrisno, Agoes. 2004. "Auditing (Pemeriksaan Akuntansi)". Edisi Ketiga. Fakultas Ekonomi Universitas Indonesia. Jakarta.

Yanuar, Y., dan Hakim, L. 2004. Pemrograman Delphi dengan Database Microsoft SQL Server. Elek Media Komputindo. Jakarta. 